\title{
INVESTIGATION OF EFFECTS OF DIFFERENT PARAMETERS ON MECHANICAL PROPERTIES IN FRICTION STIR WELDING OF AZ31B MAGNESIUM ALLOY
}

\author{
Vedat Veli ÇAY ${ }^{1, *}$, Nida KATI ${ }^{2}$, Sermin Ozan ${ }^{2}$, Veysel YAPICI ${ }^{3}$ \\ ${ }^{* 1}$ Civil Aviation School, Dicle University, Diyarbakır \\ ${ }^{2}$ Metallurgy and Materials Engineering Department, Firat University, Elazı̆̆ \\ ${ }^{3}$ Gazi Vocational High School, Elazı̆
}

*Corresponding athour; Email: vedatcay@yahoo.com

Received: 15 February 2017; Accepted: 12 May 2017

\begin{abstract}
In recent year, the use of magnesium alloys in aerospace, space, and automotive industry as structural materials has gradually been increased. The solid state welding method for joining of these materials were effective. The friction stir welding is one of the solid state welding method. In this study, the weldability of rolled AZ31B magnesium sheets has been investigated by friction stir welding. Samples have been welded at different welding parameters such as the 1500, 2300 rpm rotational speeds and 100,160 and $190 \mathrm{~mm} / \mathrm{min}$ transverse speeds. In order to investigate the effect of welding speeds and rotational speeds on metallurgical and mechanical properties, metallographic and mechanical tests were carried out on the welded areas of the samples.
\end{abstract}

Keywords: Welding, Friction stir welding, Magnesium alloys, Tensile strenght

\section{Introduction}

Magnesium is a widely used metal in industry due to its lightness and strength. In search of weight saving in automotive and space-aircraft industries, magnesium metal comes to the forefront as the lightest structural metal in terms of engineering applications with its low density of $1.74 \mathrm{~g} / \mathrm{cm}^{3}$ [1]

The fact that the magnesium is lighter than steel and zinc by $75 \%$ and aluminium by $33 \%$ makes it usable as a construction material in many industries. In addition, low inertia caused by the low density of magnesium is an advantage for fast moving parts. The lightness also means the easier transportation of the piece during manufacturing and cheaper shipment of the finished product. Thus, fuel consumption and emissions can be reduced. When magnesium alloys are compared with other metal alloys, it has a very high specific tensile compressive strength and a lower modulus of elasticity and thus a very high deflection resistance [2]. 
Along with major developments in metal and material science in recent years, the joining of metallic materials has gained a great importance [3]. Especially the problems arising from the production of new materials with improved properties and joining of these materials with existing fusion welding methods have led researchers to develop new joining methods. High heat input in joining magnesium and its alloys by using fusion-based welding methods can cause the formation of cracks in the welding seam as a result of high thermal expansion of these materials and the wide range of solidification temperatures [4]. In some alloys, the thermal cycle during welding causes the components in the main solid solution to precipitate in the molten zone or base material. This precipitation reduces mechanical properties and resistance to chemical impacts. Due to these reasons, it is difficult to weld magnesium plates by using fusion welding methods. Friction Stir Welding, one of the solid state welding methods, provides great advantages in joining these materials [5-7]. Friction Stir Welding, a newly developed solid state welding method, involves immersing a stepped stirrer tip rotating at high speed on an interface of two sheets fixed as butt-to-butt and moving it at a certain speed across the length desired to be welded $[4,8]$.

In the literature, it is possible to encounter many studies on $\mathrm{Al}$ and its alloys by using the friction stir welding method. However, there is a limited number of studies on magnesium and its alloys. The aim of this study was to investigate the effect of different rpm and feed rate on mechanical behaviours by joining AZ31B magnesium sheets via friction stir welding method.

\section{Material and Method}

In the experimental study, AZ31B magnesium alloy was commercially supplied in the form of a plate with the dimensions of 400x1000x5 mm from VIG Machinery Industry Trade Limited Company (VIG Makine Sanayi Ticaret Limitet Şirketi) and it was sized for welding as shown in Figure

1. Table 1 shows the chemical composition of this alloy.

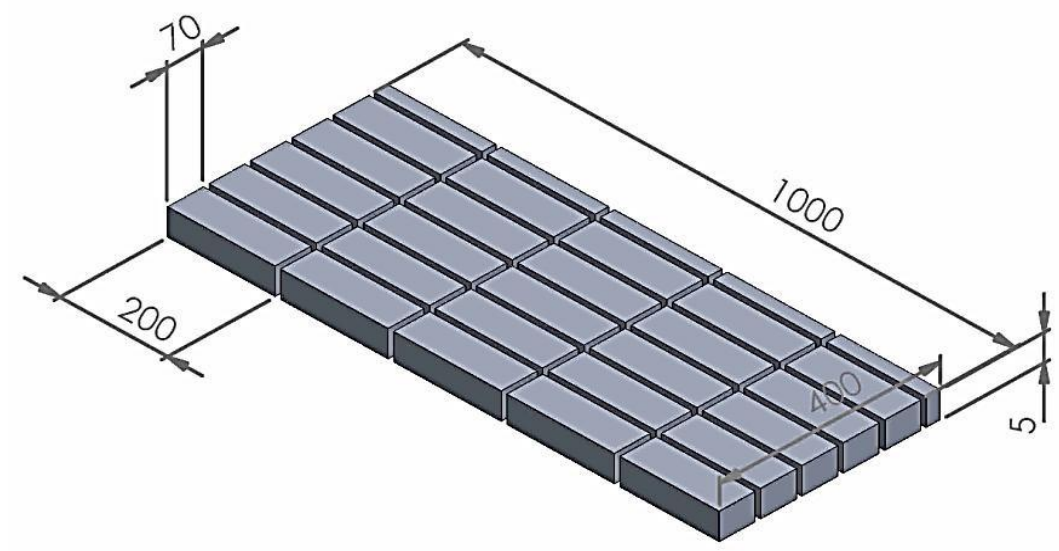

Figure 1. Sample dimensions of AZ31B Magnesium alloy supplied from the market and prepared for Friction Stir Welding 
Table 1. Chemical composition of AZ31B magnesium alloy

\begin{tabular}{|l|l|l|l|l|l|l|l|l|l|l|l|}
\hline AZ31B & Al & Zn & Mn & Si & Fe & Sn & Ag & Ti & Cu & Ni & Mg \\
\hline$\%$ & 3.0 & 1.01 & 0.2113 & 0.0137 & 0.0039 & 0.0015 & 0.0006 & 0.0005 & 0.0004 & 0.0002 & 95.72 \\
\hline
\end{tabular}

Friction stir welding (FSW) process of the samples prepared for the welding process was performed by using BRIGGEPORT brand milling machine with max. 4600 rpm operating capability, adjustable rpm and adjustable feed rate in automatic position.

A tip in the form of screw tip geometry was used during the friction stir welding. Tips were designed in 2 parts so that their shoulder parts and tip parts were separate. While shoulder parts were made from AISI 1040 steel, tip parts were made from M5 guidance HSS steel.

As shown in Figure 2, the shoulder part was drilled thoroughly for screw tip, threaded into Ø 5 mm guide shoulder, and welded from the top.
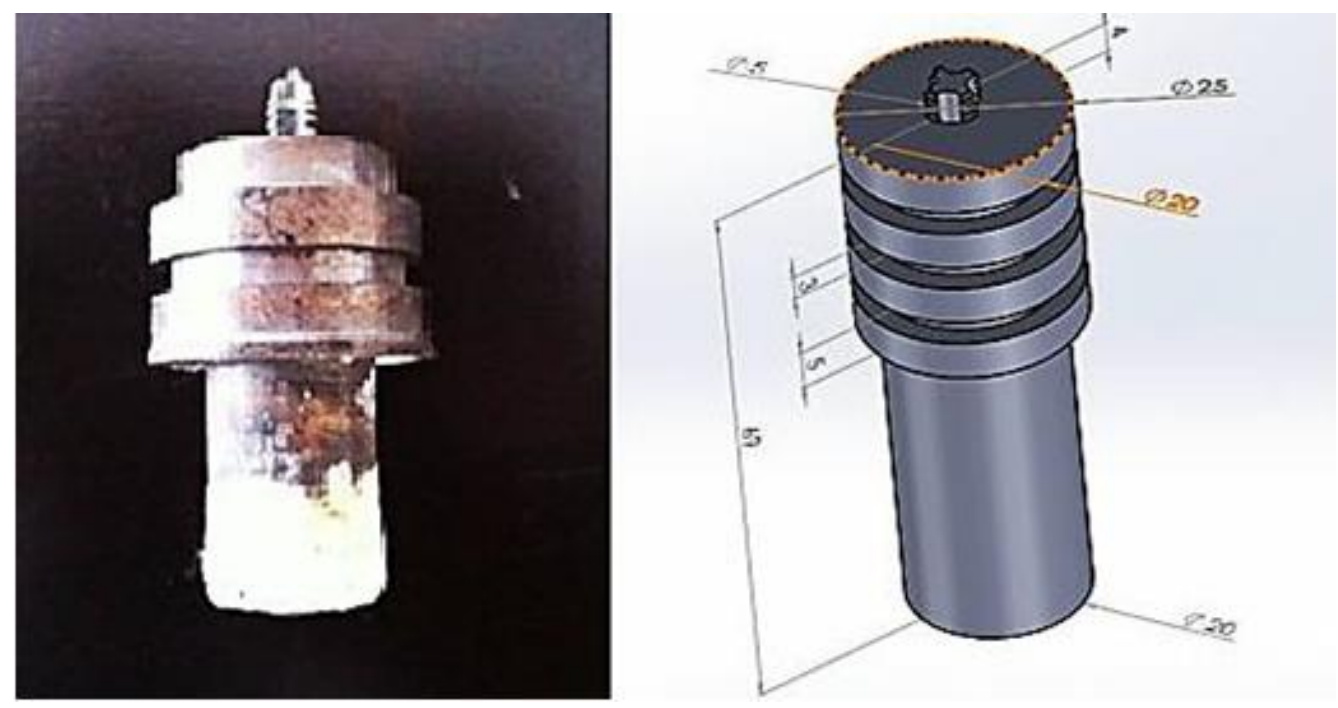

Figure 2. The schematic diagram of tool geometry.

After cleaning the welding surfaces of the materials to be welded, they were put as butt-tobutt. The sheets put as butt-to-butt were connected to the table and the weld line of the sheets was adjusted in parallel with the feed direction of the milling table and tightened with the fishplates (Fig. $3)$.

Friction stir welding was applied to magnesium alloy plates by using the welding parameters given in Table 2. 


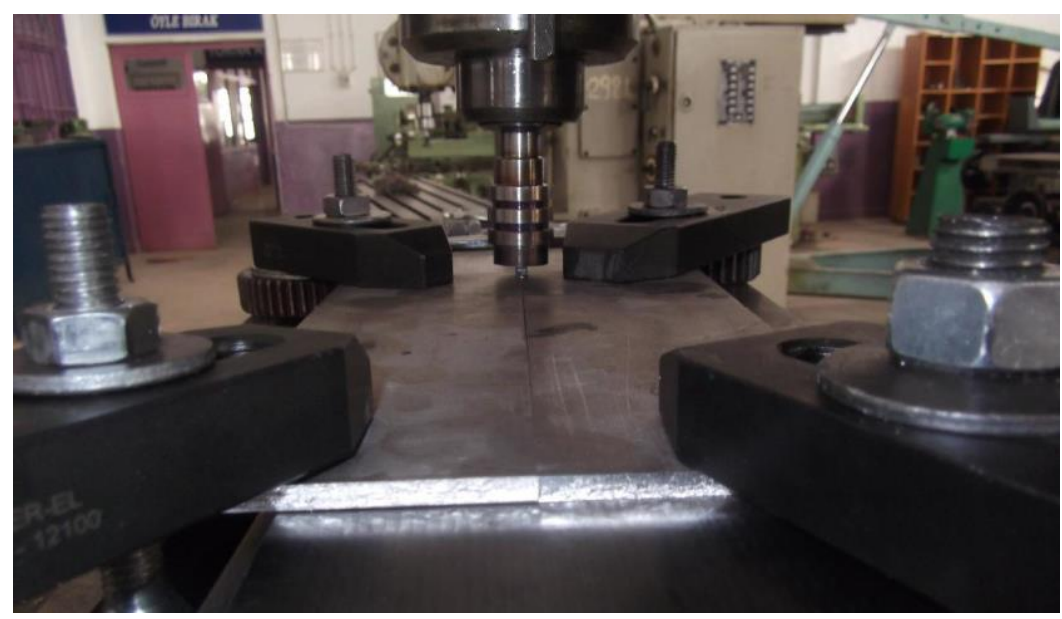

Figure 3. Fixture mechanism of the material couple to the milling machine

Table 2 Friction stir welding parameters

\begin{tabular}{|c|c|c|c|}
\hline Sample No & Pin Geometry & $\begin{array}{c}\text { Rotational speed } \\
\text { (rpm) }\end{array}$ & $\begin{array}{l}\text { Travel speed } \\
(\mathrm{mm} / \mathbf{m i n} .)\end{array}$ \\
\hline S1 & \multirow{6}{*}{ Screw } & \multirow[b]{3}{*}{1500} & 100 \\
\hline $\mathbf{S 2}$ & & & 160 \\
\hline $\mathbf{S 3}$ & & & 190 \\
\hline$\overline{S 4}$ & & \multirow{3}{*}{2300} & 100 \\
\hline $\mathbf{S 5}$ & & & 160 \\
\hline$\overline{S 6}$ & & & 190 \\
\hline
\end{tabular}

In the friction stir welding process, no deoxidization process was performed to the magnesium alloy prior to the welding process of the material, and the welding process was performed at the stages shown in Figure 4.

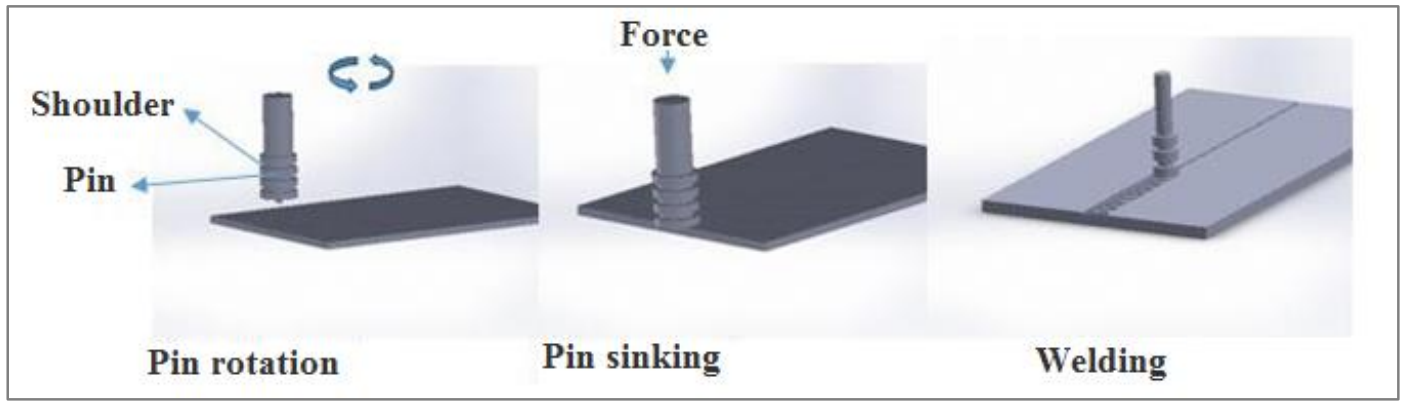

Figure 4. Stages of FSW

\subsection{Microhardness Measurements}

Microhardness measurements were performed to examine the hardness changes of the samples joined with friction stir welding. Before the microhardness measurements, the samples were 
metallographically prepared and etched. The microhardness measurements of the etched samples were carried out by applying a load of $500 \mathrm{gr}$ with the EMCOTEST DuraScan microhardness device with $1-\mathrm{mm}$ intervals and a loading speed of $10 \mathrm{sec}$ on a line perpendicular to the weld cross section from the central axis of the samples.

In the measurements, $136^{\circ}$ square base pyramid tip was used. Figure 5 shows the regions where the microhardness measurements were made.

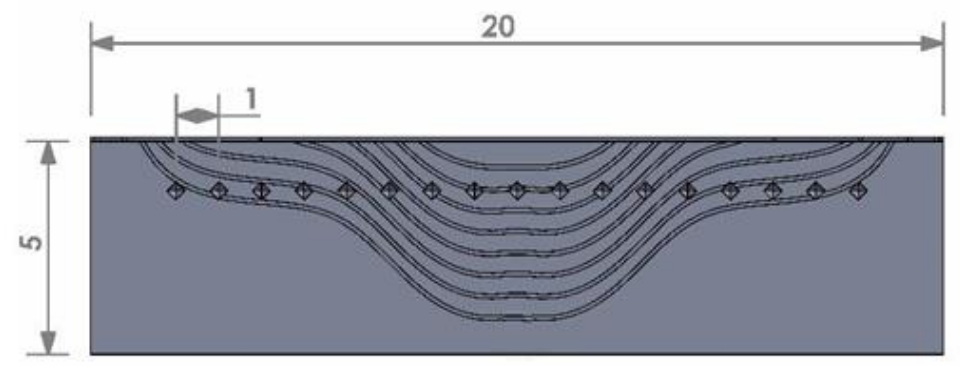

Figure 5. Hardness measurement scheme

\subsection{Tensile Tests}

Welded samples were prepared by cutting in CNC milling machine in order to apply tensile test to the friction stir welded samples. They were machined as in Figure 6 and brought into the appropriate sizes according to TS 287 (EN 895).

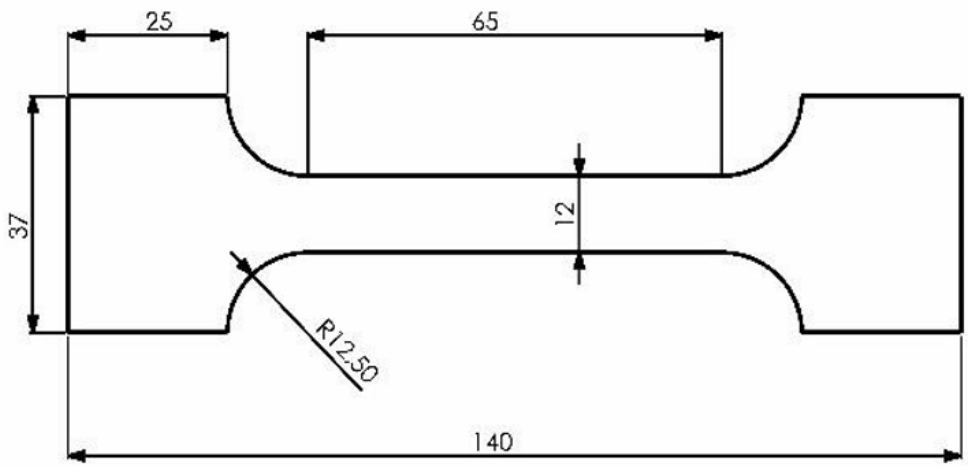

Figure 6. Schematic sketch of tensile specimen.

\section{Result and Discussion}

When friction stir welded samples were examined, it was observed that the microstructure zone of the welded sample was composed of four different zones. These zones were analysed as Base Metal (BM), Heat Affected Zone (HAZ), Thermo-mechanically Affected Zone (TMAZ) and Dynamically Recrystallized Zone (DRZ) as in figure. The DRZ is also divided into two namely, Crown and Nugget. (Fig. 7) 


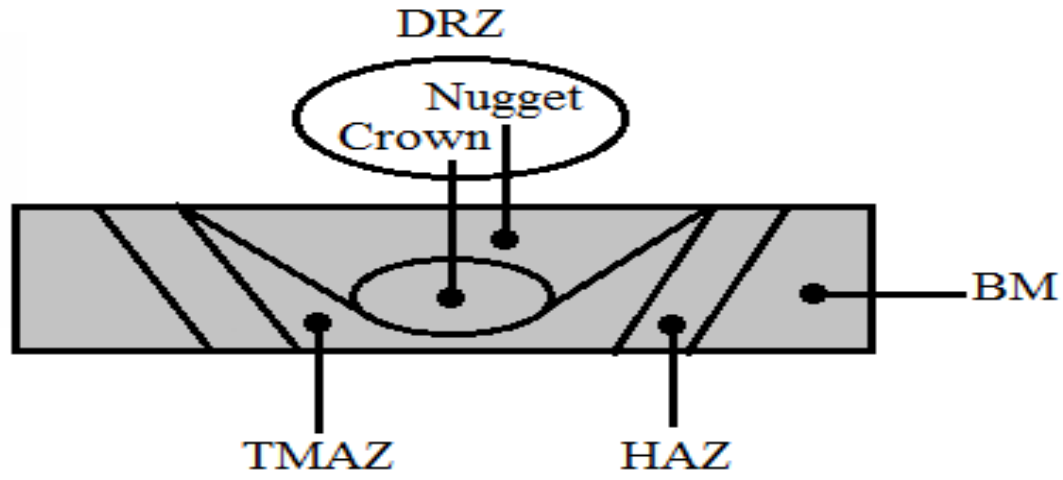

Figure 7. Schematic view of the microstructure formed in the weld region.

\subsection{Microhardness}

Before performing welding process to $\mathrm{AZ} 31 \mathrm{~B} \mathrm{Mg}$ alloy, 10 different points were measured and the average hardness value was calculated as $65 \mathrm{HV}$.

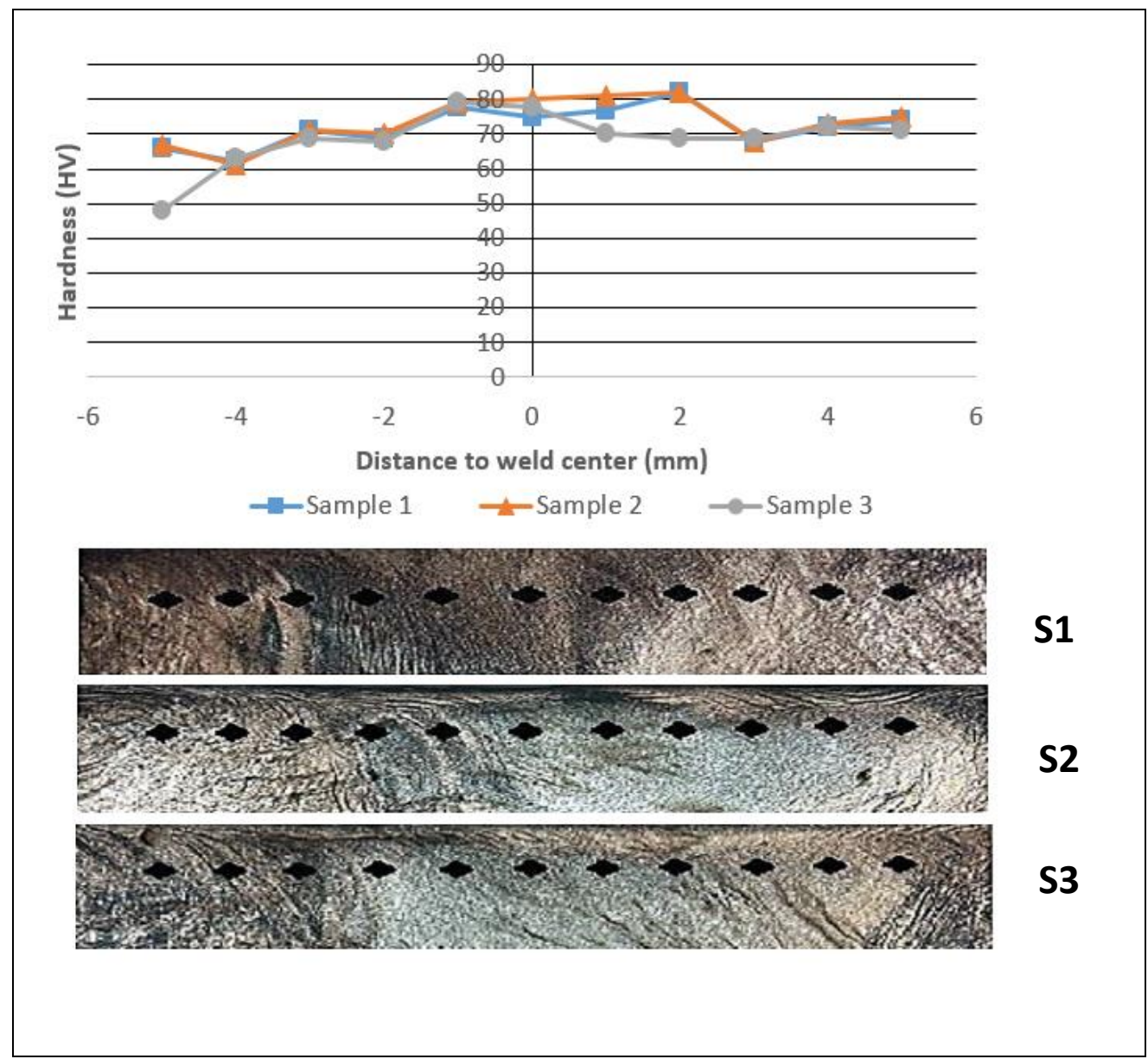

Figure 8. Hardness profiles registered across the transverse cross-section of the welded samples $(\mathrm{S} 1, \mathrm{~S} 2, \mathrm{~S} 3)$. 
Figure 8 shows microhardness graph of samples S1, S2 and S3 joined using $1500 \mathrm{rpm}$ and feed rates of 100/160/190 mm/min. It was measured that maximum hardness value of sample $\mathrm{S} 1$ was 78 vickers, maximum hardness value of sample $\mathrm{S} 2$ was 82.6 vickers and maximum hardness value of sample S3 was 77.1 vickers. This measured maximum hardness values were found in the DRZ. The hardness value of all the samples in the DRZ was higher than the hardness of the base material. The reason for this was the formation of recrystallization by the effect of plastic deformation and heat and the thinning of grain structure [9]. As we got closer to the base material from the welding interface, hardness values decreased and the results close to the hardness values of the base material were obtained.

When the hardness distribution was examined, hardness decreased in a zone starting from the weld zone and close to the surrounding of the tool shoulder. The hardness values increased when it moves away from the centre in the tool shoulder length. This was associated with the reduction of heat effect in these zones.

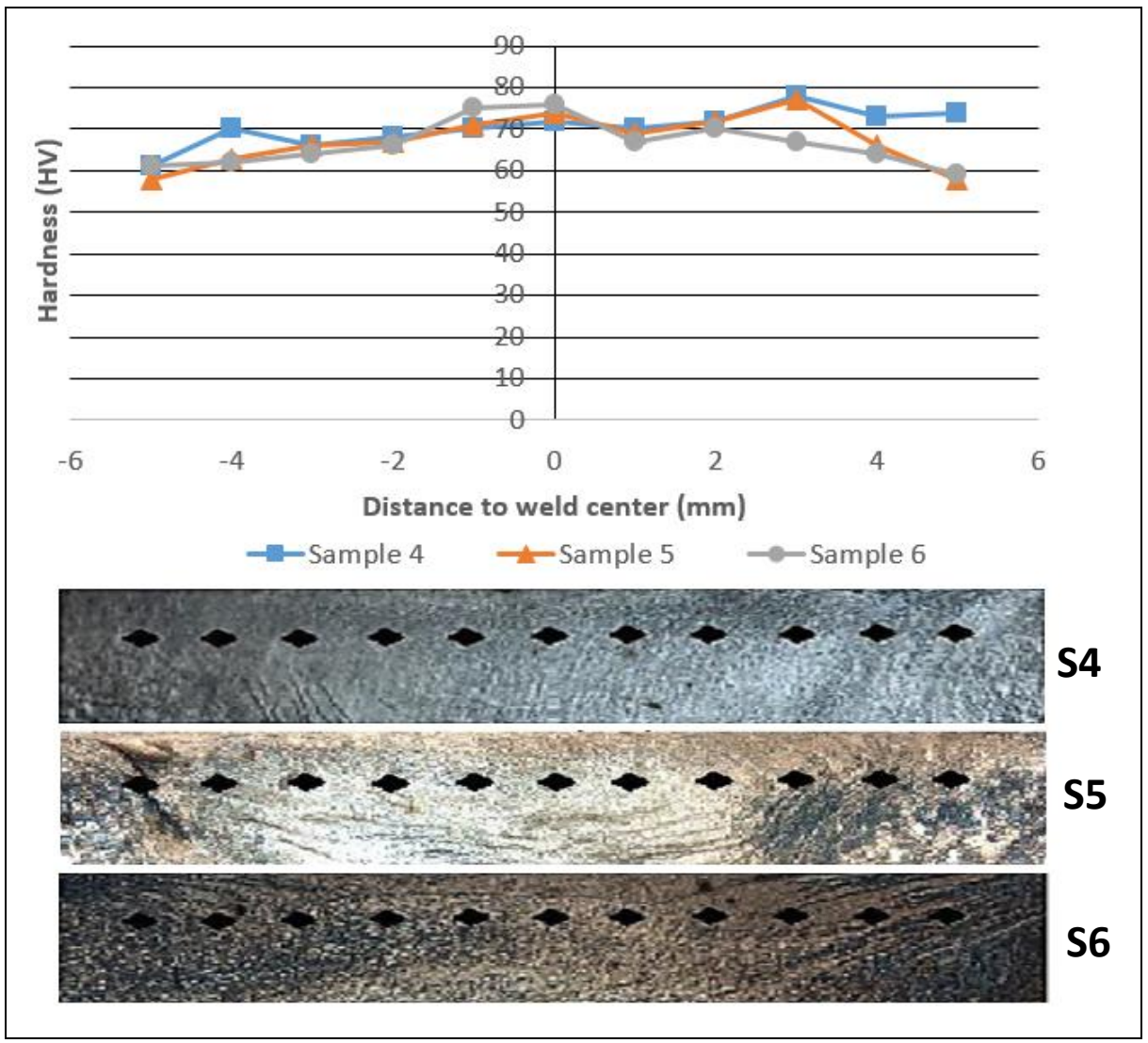

Figure 9. Hardness profiles registered across the transverse cross-section of the welded samples $(\mathrm{S} 4, \mathrm{~S} 5, \mathrm{~S} 6)$.

Fig. 9 shows microhardness graph of samples S4, S5 and S6 joined using $2300 \mathrm{rpm}$ and feed rates of 100/160/190 $\mathrm{mm} / \mathrm{min}$. It was measured that maximum hardness value of sample $\mathrm{S} 4$ 
was 78 vickers, maximum hardness value of sample S5 was 76,5 vickers and maximum hardness value of sample S6 was 74,6 vickers. When the hardness distributions of these welded connections are examined, it is seen that there is a similar distribution in all three samples.

When microhardness values of specimens at $1500 \mathrm{rpm}$ and $2300 \mathrm{rpm}$ were evaluated, no significant differences were found. However, depending on the increasing rotational speed, the hardness values of S4, S5 and S6 were slightly lower. However, depending on the increasing speed of rotation, the hardness values of S4, S5 and S6 were slightly lower. This is due to the excess heat input to the sample, depending on the speed of rotation.

\subsection{Tensile Properties}

Figure 10 shows tensile-strain graphs of all samples. When the graph of the S1 sample joined with $1500 \mathrm{rpm}$, screw tip and $100 \mathrm{~mm} / \mathrm{min}$ feed rate was examined, it was observed that tensile stress was $79 \mathrm{Mpa}$, the breaking stress was $77 \mathrm{Mpa}$ and \% elongation value was 1.5. It was observed that the tensile stresses of samples S2/S3 were 80/109 Mpa, the breaking stresses were 80/109 Mpa and $\%$ elongation values were 1.8/2.1 in the welding process in the same rpm with $160 \mathrm{~mm} / \mathrm{min}$ and 190 $\mathrm{mm} / \mathrm{min}$ feed rates respectively.

When fracture surface images of the samples were examined, the part under the shoulder of the mixer (crown region) showed work hardening due to the effect of stirring and the strength increased and the samples fractured from a point between the heat-affected zone (HAZ) and the thermodynamically recrystallized zone (TMAZ) [10]. No significant change in tensile values was observed with increasing welding speed.

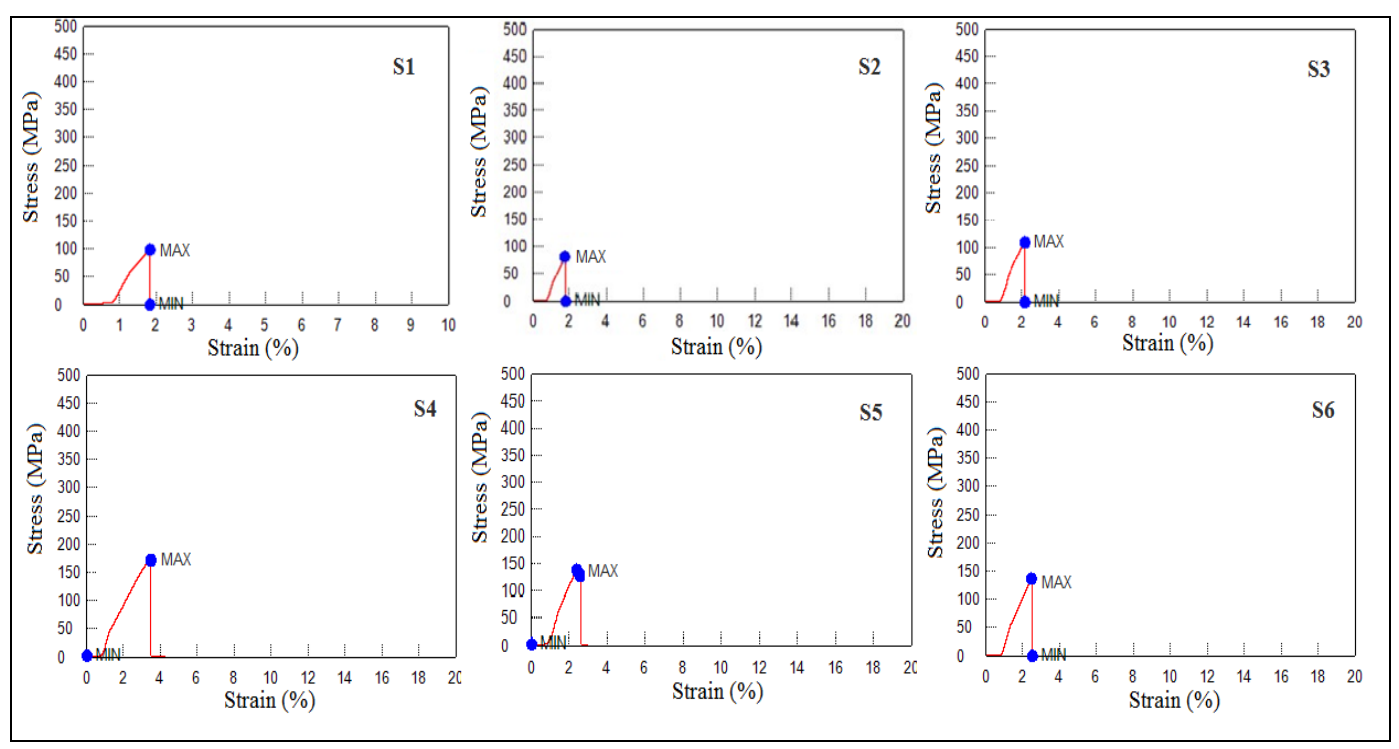

Figure 10. Example stress-strain curves of all samples 
It was seen from Figure 10 that tensile stress was $173 \mathrm{Mpa}$, breaking stress was $171 \mathrm{Mpa}$ and $\%$ elongation value was 3.5 in the stress/strain graphs of sample S4 joined with $2300 \mathrm{rpm}$, threaded tip and $100 \mathrm{~mm} / \mathrm{min}$ feed rate. When the graphs of samples S5/S6 at different feed rates were examined, it was determined that the tensile stresses were 138/136 Mpa, breaking stresses were 127/136 Mpa and \% elongation values were 2.6/2.5, respectively. Table 3 shows the welding parameters of all samples and the strength values obtained from tensile test.

The tensile strength values of the samples in this group decreased with increasing feed rate. This is because the amount of heat entering the material reduced, so the grain coarsening also occurred less. When the fracture surface images of samples S4, S5, and S6 were examined, it was determined that the fracture sites were in the region between the thermodynamically affected zone (TMAZ) and the heat-affected zone (HAZ) as in the other sample groups.

Tablo 3. FSW parameters and results of tensile test

\begin{tabular}{|c|c|c|c|c|c|c|}
\hline $\begin{array}{l}\text { Sample } \\
\text { No }\end{array}$ & $\begin{array}{c}\text { Pin } \\
\text { Geometry }\end{array}$ & $\begin{array}{c}\text { Rotational } \\
\text { speed } \\
(\mathbf{r p m})\end{array}$ & $\begin{array}{c}\text { Travel } \\
\text { speed } \\
(\mathrm{mm} / \mathrm{min} .)\end{array}$ & $\begin{array}{l}\text { Ultimate } \\
\text { tensile } \\
\text { strenght } \\
\text { (Mpa) }\end{array}$ & $\begin{array}{c}\text { Yield } \\
\text { strenght } \\
\text { (Mpa) }\end{array}$ & $\begin{array}{c}\text { Elongation } \\
(\%)\end{array}$ \\
\hline S0 & & & & 274 & 271 & 10 \\
\hline S1 & \multirow{6}{*}{ Screw } & \multirow{3}{*}{1500} & 100 & 79 & 77 & 1,5 \\
\hline S2 & & & 160 & 80 & 80 & 1,8 \\
\hline S3 & & & 190 & 109 & 109 & 2,1 \\
\hline S4 & & \multirow{3}{*}{2300} & 100 & 173 & 171 & 3,5 \\
\hline S5 & & & 160 & 138 & 127 & 2,6 \\
\hline S6 & & & 190 & 136 & 136 & 2,5 \\
\hline
\end{tabular}

Even though the related studies have revealed that the most important parameters affecting the welding quality are feed rate and rotational speed of the tip, the rotational speed of the tip rather than the feed rate was found to be effective in the present study. A quite brittle structure formed in the weld zone in welding of Mg alloys [11]. This is because the Mg alloy has a hexagonal closest- packed (HSP) lattice system and a cross- shifting is observed in these materials. When the stress-strain curves were examined, it was observed that tensile sample stretched in a very low rate and the material fractured even before passing to the plastic zone [12] This is because the weld zone had a very fragile structure and also there were porosities in the weld zone. 


\section{Conclusions}

In this study, $5 \mathrm{~mm}$-thick AZ31B magnesium alloy sheets were successfully joined by using friction stir welding method with different rpm values and feed rates and the following generalizations can be made depending on the results obtained with the effects of these parameters on the mechanical properties.

1. It was observed that welding seam image of the samples joined with friction stir welding was much smoother than the other welding methods and no machining process was necessary.

2. Weld defect (gap) occurred in all samples of AZ31B magnesium alloy in FSW. Such gap defects have also been determined in other studies in the literature. This situation is one of the characteristic faults occurring at the welding of magnesium alloys.

3. It was observed in all welded samples that the orientations in weld metal with the increasing welding feed rate increased but the orientations in the weld metal at low feed rates were not evident.

4. When the microhardness values of samples $S 1(100 \mathrm{~mm} / \mathrm{min}), \mathrm{S} 2(160 \mathrm{~mm} / \mathrm{min})$ and $\mathrm{S} 3$ (190 $\mathrm{mm} / \mathrm{min}$ ) welded at $1500 \mathrm{rpm}$ and screw tips were examined, hardness values close to each other were obtained in each of three samples. Accordingly, it was thought that the feed rate did not have any significant effect on the hardness of the welded joint.

5. Hardness values close to each other were also obtained in the samples $\mathrm{S} 4(100 \mathrm{~mm} / \mathrm{min})$, S5 $(160 \mathrm{~mm} / \mathrm{min})$ and S6 $(190 \mathrm{~mm} / \mathrm{min})$ welded with $2300 \mathrm{rpm}$ and threaded tip.

6. When the tensile strength results of all the samples were examined, it was observed that these values were lower than the tensile strength value of the base material. When the tensile test results were examined, it was observed that the fractures occurred usually in the zones between the thermo-mechanically affected zone (TMAZ) and the heat-affected zone (HAZ). The reason for occurrence of the fractures in these zones was the formation of grain coursing due the heat effect and thus the decrease of the strength in this transition zone.

\section{References}

[1] Zeytin, H.K., Magnezyum Alaşımları: Otomotiv Endüstrisinde Uygulaması ve Geleceği, Marmara Araştırma Merkezi, Kocaeli 1999

[2] Mert, F., Özdemir, A., Karatas, Ç., Magnezyum Alaşımlarının Basınçlı Döküm Yöntemiyle Kalıplanabilirliğinin Değerlendirilmesi, Journal of Polytechnic 13 (2010) 3 pp 165-176

[3] Thomas, W.M., Nicholas, E.D., Friction Stir Welding for the Transportation Industries, 
Material Desing, 18 (1997) 269-273.

[4] Özdemir, N., Büyükarslan, S., Sarsılmaz, F., Sürtünme Karıştırma Kaynak Yöntemi ile Birleştirilmiş AA1030 Alüminyum Alaşımında Karıştırıcı Uç Profili ve İlerleme Hızının Arayüzey Mikroyapı Değişimi Üzerine Etkisi, Fırat Ünv. Fen ve Müh. Bil. Dergisi, 19 (2007) 3 407-415.

[5] Johnsen M.R., Friction Stir Welding Takes Off at Boeing, Welding Journal, Cambride UK, (199) 35-39.

[6] Çam, G., Sürtünme Karıştırma Kaynağı ve Uygulamaları, PAÜ Müh. Fak. 9. Denizli Malzeme Seтроzуити (2002) 450-458.

[7] Metal Handbook, Nonferrous Alloys an Special Purpose Materials, Volume: 2 ASM 1993.

[8] Şık, A., Sürtünme Karıştırma Kaynağı ile Birleştirilen Magnezyum Levhaların Mekanik Özelliklerinin İncelenmesi, SAÜ. Fen Bil. Der. 14 (2010) 2 s 134-140.

[9] Fujii, H., Cui, L., Maeda, M., Nogi K., Effect Of Tool Shape On Mechanical Properties and Microstructure of Friction Stir Welded Aluminum Alloys, Materials Science and Engineering: A, (2006) 419, 25-31.

[10] Cavaliere P., Cerri, E., Mechanical Response of 2024-7075 Aluminium Alloys Joined By Friction Stir Welding, Journal of Materials Science, 40 (2005) 3669 - 3676.

[11] Ericsson M., Jin, L.Z., Sandström R., Fatigue properties of friction stir overlap welds, International Journal of Fatigue, 29 (2007) 57-68.

[12] Cavaliere, P., Squillace, A., High temperature deformation of friction stir processed 7075 aluminium alloy, Materials Characterization, 55 (2005) 136-142. 